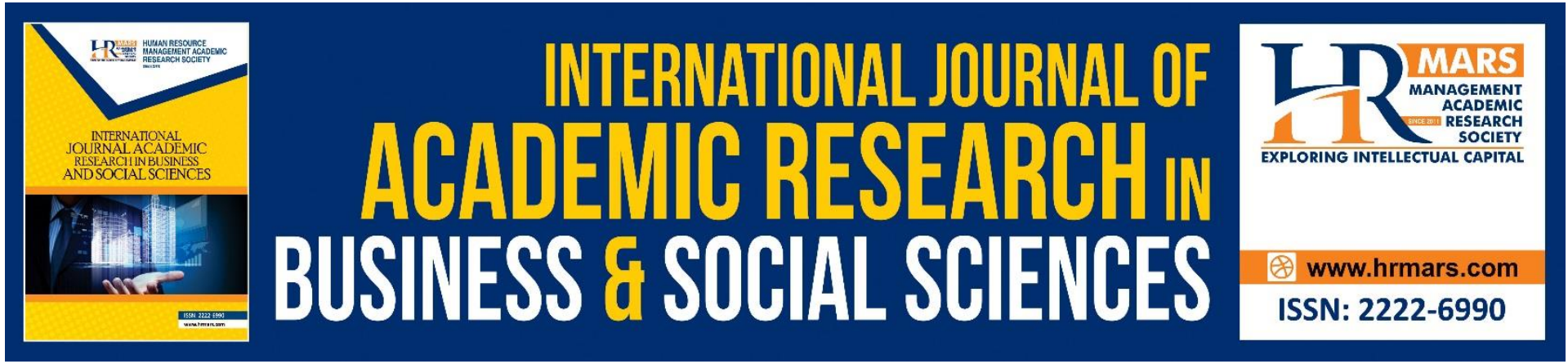

\title{
Online Learning During Ongoing Covid-19 Pandemic: A Survey of Students' Satisfaction
}

Nor Azwahanum Nor Shaid, Fathiyah Mohd Kamruzaman \& Nur Ainil Sulaiman

To Link this Article: http://dx.doi.org/10.6007/IJARBSS/v11-i7/10557

DOI:10.6007/IJARBSS/v11-i7/10557

Received: 25 May 2021, Revised: 28 June 2021, Accepted: 10 June 2021

Published Online: 29 July 2021

In-Text Citation: (Shaid et al., 2021)

To Cite this Article: Shaid, N. A. N., Kamruzaman, F. M., \& Sulaiman, N. A. (2021). Online Learning During Ongoing Covid-19 Pandemic: A Survey of Students' Satisfaction. International Journal of Academic Research in Business and Social Sciences, 11(7), 924-937.

Copyright: (c) 2021 The Author(s)

Published by Human Resource Management Academic Research Society (www.hrmars.com)

This article is published under the Creative Commons Attribution (CC BY 4.0) license. Anyone may reproduce, distribute, translate and create derivative works of this article (for both commercial and non-commercial purposes), subject to full attribution to the original publication and authors. The full terms of this license may be seen at: http://creativecommons.org/licences/by/4.0/legalcode

Vol. 11, No. 7, 2021, Pg. 924 - 937

Full Terms \& Conditions of access and use can be found at http://hrmars.com/index.php/pages/detail/publication-ethics 


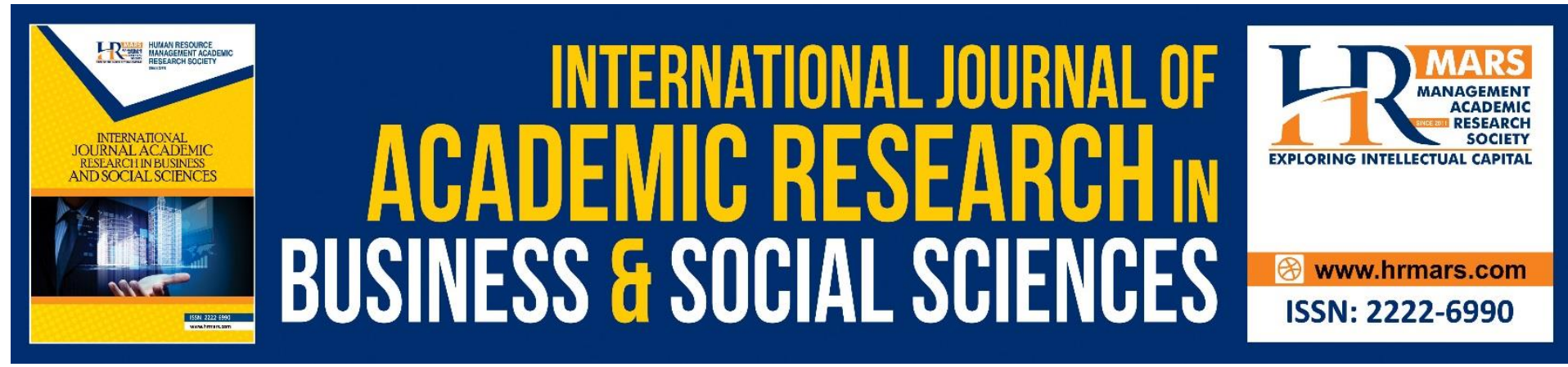

\title{
Online Learning During Ongoing Covid-19 Pandemic: A Survey of Students' Satisfaction
}

\author{
Nor Azwahanum Nor Shaid, Fathiyah Mohd Kamruzaman \& \\ Nur Ainil Sulaiman
}

Faculty of Education The National University of Malaysia, Malaysia

Email: fathiyah@ukm.edu.my

\begin{abstract}
The educational system across the world had immensely been affected due to COVID-19 outbreak. Teaching and learning shifted from traditional way which involves face-to-face interaction and in physical classroom, to online learning either synchronously or asynchronously. Therefore, the aim of this study to examine the level of students' satisfaction towards online learning implemented at the higher education level during the ongoing COVID19 pandemic. The study adopted the quantitative approach through survey which was collected through online questionnaire. The study respondents were drawn from 65 undergraduate students enrolled in online leaning at Faculty of Education, The National University of Malaysia. Data collected were analysed using Statistical Package Social Science 23 (SPSS 23) software and presented in the form of percentages and mean scores. The study revealed that undergraduate students were satisfied towards the use of online learning in term of learners' dimension ( $M=3.31)$, technology characteristics $(M=3.66)$ and instructor characteristics $(M=3.70)$. The study revealed the students had positive perceptions towards online learning and accepted this as the new learning system. In fact, online learning has emerged as a new way of enhancing the learning process. The findings of the study will facilitate educational institutions and policy makers to take this online learning process to the next level in a better way.
\end{abstract}

Keywords: COVID-19, Online Learning, Satisfaction

\section{Introduction}

The Corona Virus Disease 2019 (COVID-19) has infected millions of people worldwide and been declared as a global pandemic by the World Health Organization on March 2020. This resulted many countries around the world to made decisions to temporarily close all academic institutions to break the COVID-19 chain (Alawamleh, 2020). This matter has affected almost $80 \%$ of the world's student population of nearly 1.37 billion students of 138 countries and 60.2 million teachers were unable to be in the classroom due to the closure of schools and universities (UNESCO 2020).

Accordingly, in March 2020 Malaysia government has announced The Movement Control Order (MCO) nationwide to curb the spread of COVID-19. In line with this action, public and private academic institutions have been shut down since March 2020 (Tang, 2020). Therefore, 
universities have resorted to continue lectures via online learning and no more physical classes were allowed since April 2020 (Chung \& Mathew, 2020). This shifted was made as a precaution needed to control this pandemic. Hence, this influences students' satisfaction towards learning in general as online learning differs from face-to-face lectures.

Previously, online learning has been regarded as temporary solution and never been fully adopted as formal mode of education (Mahajan, 2018). Currently, amidst the ongoing spread of COVID-19, most of the educational institutions opted online learning as an alternative for students to study and considered it as a new norm. Previous studies showed that online learning can be a catalyst in an active learning, enhancing students' creativity and motivation for learning (Cidral et al., 2018; Pei et al., 2019). In this current situation, the contribution of online learning is inevitable as it provides opportunity for educators to carry on their teaching. However, despite its multiple advantages as compared to traditional learning, there are several challenges of online learning faced by the students (Dawadi et al., 2020; Mustapah \& Rosli et al., 2021). Study conducted by Sá \& Serpa (2020) reported that factors such as social isolation, problem in face-to-face interaction between teacher and student, connectivity issues, and few others are among the issues related to online learning.

Hence, it is important to explore the learners' perception and inclination of online learning approach that suits their need. Moreover, there is a need to conduct a comprehensive study to understand learners' satisfaction towards online learning for effective implementation of the program. In accordance to learners' needs, the present study aims to assess the level of satisfaction of undergraduate students towards online learning utilized by the university in term on methods and approaches used during this COVID-19 pandemic. It is hoped to provide insights on steps necessary for further improvement.

Consequently, this study intends to seek whether online learning has as an effect on students' satisfaction in which may affect students' productivity levels. Since the shift to online learning due to $\mathrm{MCO}$ is very new to most students and instructors in Malaysia, there is a great interest in this topic. Three research questions are addressed in this study as follow;

1. What is the level of satisfaction towards online learning from learners' dimension during COVID-19 pandemic?

2. What is the level of satisfaction towards online learning in terms of technology characteristics utilized during COVID-19 pandemic?

3. What is the level of satisfaction towards online learning in terms of instructor characteristics during COVID-19 pandemic?

\section{Literature Review \\ Online Learning}

Due to the spread of this disease and its contagious nature, face-to-face classes has shifted to online learning. Online learning is considered as an alternative learning method with the use of computers, laptops, tablets and mobile phones with internet access in synchronous and asynchronous environments. Through these learning methods and environments, students have a freedom in learning and get connected with their teachers anywhere they want (Singh \& Thurman, 2019). There are two modes in online learning: 1) synchronous mode which provides the direct interaction between the lecturers and students during class through tools such as videoconference or chatrooms; and 2) asynchronous mode that provides the opportunity for the lecturers and students to interact each other before or after the online class through thread discussion and emails (Algahtani, 2011). 
Previous studies have shown that online learning has many advantages and benefits to learners (Shen \& Chuang, 2010). The online learning provides advantages in independent learning and developing new skills in the process leading to life-long learning (Dhawan, 2020). On the other hand, The Regional Risk Communication and Community Engagement (RCCE) Working Group (2020) stated that online learning can be challenging to the underprivileged, disabled, and marginalized students who had limited accessibility and resources to online learning. Their inability to access and participate in online learning causes the disparity and dropout among them. Besides that, online learning also requires students' commitment and discipline, especially for vulnerable students who need interaction that allows them to strengthen their social skills (UNESCO, 2020).

\section{Student Satisfaction of Online Learning}

Satisfaction is a consideration or decision that provides a level of consumption against a particular feature of a product and service itself (Parahoo et al., 2016). In addition, learning satisfaction represents the construct of students' attitudes that measures affectively students' satisfactions who usually have positive experience towards online learning (Harsasi, et al., 2018). The key to the success of online learning is when the student feels satisfied with the learning method itself (Dziuban et al., 2015; Rios, Elliot \& Mandernach, 2018). Satisfaction is one of the important steps to determine the quality of an online learning. Meanwhile, student satisfaction also can be defined as students' perception towards learning experience which can be increased when learning is planned, and they be able to reflect learning and the provision of appropriate platforms for interaction and collaboration between teachers and students (Rios, Elliott, \& Mandernach, 2018).

Numbers of previous studies have been conducted to measure the level of student satisfaction with online learning (Gray \& Diloreto, 2016; Harsasi \& Sutawijaya, 2018; Nortvig et al., 2018). Past studies have shown that satisfied students appear to be engaged, motivated and responsive; contribute to an effective learning climate; and achieve higher levels of performance. However, when students felt dissatisfied or ambivalent, it can affect overall outcomes where instructors appear to have much more difficulty facilitating effective learning situations (Dziuban et al., 2007).

\section{Methodology}

This study is survey study which was conducted to explore and elaborate students' satisfaction towards online learning. The total number of respondents participated in this study was 65 undergraduate students from Faculty of Education, The National University of Malaysia. The students were from various majors including Special Education, Sports and Recreation and Teaching English as a Second Language (TESL). They are actively involved in online learning where all the subjects are taught via online learning platform such as Google Meet, Zoom, UKMFolio and many more.

The instrument used in this study was developed based on prior literature related to online learning and students' satisfaction. To achieve the objectives of the study, the researcher adapted 30 items from two questionnaires from Sharma et al. (2020) and Cole et al. (2014). The questionnaire consisted of two sections. Section A comprises of personal information of the respondents, while Section B is divided into three domains which are Domain 1: Learner's dimension; Domain 2: Technological Characteristics; and Domain 3: Instructors' Characteristics. Each item of the domains was rated in 5-point Likert scale: (1) highly dissatisfied; (2) no satisfied; (3) uncertain; (4) satisfied; and (5) very satisfied. 
The questionnaire was distributed using Google Forms and was piloted among 35 undergraduate students from different disciplines. To verify the reliability of the instrument, Cronbach's alpha was calculated using the pilot study data. The Cronbach's alpha for the instrument was 0.973 indicating that the tool has a strong reliability level. Two items were removed because of its' poor mean value in the domain. The questionnaire is then finalized after minor changes required after pilot survey for the assessment of feasibility of the survey. It is important step to test the reliability of the instrument, as it checks the internal consistency and inspects the properties of measuring scale (Hair et al., 2006). This study used Cronbach's alpha as a measure of reliability, which is a commonly applied measure in Likert scale survey questions. The information presented here is prepared by the researchers through Statistical Package for Social Sciences (SPSS) Output. Table 1 gives the value of Cronbach's alpha for each domain of the construct considered separately.

Table 1: Reliability of The Constructs

\begin{tabular}{|c|c|c|}
\hline Domain & Cronbach's Alpha & No. of Items \\
\hline Domain 1: Learner's dimension & 0.942 & 16 \\
\hline $\begin{array}{l}\text { Domain 2: } \quad \text { Technologica } \\
\text { Characteristics }\end{array}$ & 0.902 & 9 \\
\hline Domain 3: Instructors' Characteristics & 0.974 & 13 \\
\hline
\end{tabular}

As shown in Table 1 above, the reliability value of Cronbach's alpha value for three domains used in the instrument are over 0.90 and hence hold good internal consistency allowing for further analysis. This is acknowledged by Sekaran (2016), the reliability value of Cronbach's alpha between \pm 0.41 and \pm 0.70 qualifies for moderate reliability of the scale measured, while greater value than \pm 0.70 shows high internal consistency and values between 0.70 to 0.90 exceed the level of acceptability.

The revised questionnaire then is distributed to the undergraduate students of the Faculty Education, The National University of Malaysia. A descriptive statistical analysis of the survey was conducted using the (SPSS) version 23.

The data is presented using means in figures and tables. Students' satisfaction was based on three domains: Domain 1: Learner's dimension; Domain 2: Technological Characteristics; and Domain 3: Instructors' Characteristics. The analysis of these three domains are presented separately. To answer the research questions of the study, the researcher interprets the level of students' satisfaction based on Mean Score Interpretation by Pallant (2010) as display in Table 2 below.

Table 2 Mean score interpretation

\begin{tabular}{ll}
\hline Mean score & Interpretation \\
\hline $1.00-2.33$ & Low \\
$2.24-3.67$ & Intermediate \\
$3.68-5.00$ & High \\
\hline
\end{tabular}




\section{Results and Discussion}

Profile of The Respondents

This section presents demographic information of the respondents participated in this study. Table 3 depicts, out of 65 respondents, majority of the respondents were females $67.7 \%$ and male with $32.3 \%$. Most respondents participated in this study were first year study with $63.1 \%$ and others are from second year students $23.1 \%$, third year students with $12.3 \%$ and fourth year just $1.5 \%$. They were mostly from Special Education program (56.9\%) and others were from Sports \& Recreation program (15.4\%) and Teaching English as a Second Language (TESL) program (27.7\%). As far as the sources of sample data is concerned, majority of the students $(60 \%)$ had internet facility i.e. WiFi at their home or residence that they used during the online classes. Meanwhile, the remaining $35.4 \%$ primarily used data package from telecommunication service provider while $4.6 \%$ of the students used both WIFI and data package to participate in online classes.

Table 3: Students' Demography $(n=65)$

\begin{tabular}{|ll}
\hline Characteristics & $\begin{array}{l}\text { Percentage } \\
\text { (\%) }\end{array}$ \\
\hline $\begin{array}{l}\text { Gender } \\
\text { Male }\end{array}$ \\
$\quad$ Female & 67.7 \\
\hline $\begin{array}{l}\text { Academic Year } \\
1^{\text {st }}\end{array}$ & 32.3 \\
$2^{\text {nd }}$ & 63.1 \\
$3^{\text {rd }}$ & 23.1 \\
$4^{\text {th }}$ & 12.3 \\
\hline $\begin{array}{l}\text { Programs } \\
\text { Special Education }\end{array}$ & 1.5 \\
\hline Sports \& Recreation & \\
\hline TESL & 56.9 \\
\hline Participation in class through & 15.4 \\
\hline WIFI & 27.7 \\
\hline Data package & 60.0 \\
\hline Both & 35.4 \\
\hline \multicolumn{2}{|l}{ Learners' Dimension Domain } \\
\hline
\end{tabular}

The first domain discussed in this section is satisfaction from learners' dimension. Learners' Dimension consists of 16 items (see Table 4). Out of 16 items, only three items that displayed high mean score which were "I am open to learn about new things regarding online learning" $(M=4.08)$, and "I feel students need to be trained before undergoing online learning activities" $(M=3.98)$, "Online learning saves me money I spend on printed learning materials and transportation cost" ( $M=3.74)$. From these values, it can be concluded that the students have positive attitude to adapt themselves even though most of them have never met throughout the classes.

However, the remaining 13 items from this domain shown intermediate level of satisfaction. This is in line with the findings of Mishra et al. (2020) which reported that students react 
negatively to online learning because they can't maintain good behaviour throughout the online learning as they are unable to maintain their learning abilities due to instructors' quickness towards online teaching. Overall mean scores obtained for this domain was ranked intermediate $(M=3.31)$. From this finding, it can be concluded that the students were not really satisfied with online learning.

Table 4: Distribution of Responses of the Students in Domain 1 Learners' Dimension $(n=65)$

\begin{tabular}{|c|c|c|c|c|c|c|c|}
\hline Statements & SD & D & $\mathbf{N}$ & A & SA & $\begin{array}{l}\text { Mean } \\
\text { (M) }\end{array}$ & Interpretation \\
\hline $\begin{array}{l}\text { I am open to learn } \\
\text { about new things } \\
\text { regarding } \\
\text { learning. }\end{array}$ & $\begin{array}{l}2 \\
(3.1 \%)\end{array}$ & 0 & $\begin{array}{l}13 \\
(20 \%)\end{array}$ & $\begin{array}{l}26 \\
(40 \%)\end{array}$ & $\begin{array}{l}24 \\
(36.9 \%)\end{array}$ & 4.08 & High \\
\hline $\begin{array}{l}\text { I am able to spend } \\
\text { significant time and } \\
\text { energy to engage in } \\
\text { online learning class. }\end{array}$ & $\begin{array}{l}2 \\
(3.1 \%)\end{array}$ & $\begin{array}{l}7 \\
(10.8 \%)\end{array}$ & $\begin{array}{l}21 \\
(32.3 \%)\end{array}$ & $\begin{array}{l}22 \\
(33.8)\end{array}$ & $\begin{array}{l}13 \\
(20 \%)\end{array}$ & 3.57 & Intermediate \\
\hline $\begin{array}{l}\text { I am confident while } \\
\text { using online learning } \\
\text { system. }\end{array}$ & $\begin{array}{l}4 \\
(6.2 \%)\end{array}$ & $\begin{array}{l}3 \\
(4.6 \%)\end{array}$ & $\begin{array}{l}26 \\
(40 \%)\end{array}$ & $\begin{array}{l}27 \\
(41.5 \%)\end{array}$ & $\begin{array}{l}5 \\
(7.7 \%)\end{array}$ & 3.40 & Intermediate \\
\hline $\begin{array}{l}\text { I enjoy using the online } \\
\text { platform applications }\end{array}$ & $\begin{array}{l}2 \\
(3.1 \%)\end{array}$ & $\begin{array}{l}6 \\
(9.2 \%)\end{array}$ & $\begin{array}{l}21 \\
(32.3 \%)\end{array}$ & $\begin{array}{l}22 \\
(33.8)\end{array}$ & $\begin{array}{l}14 \\
(21.5 \%)\end{array}$ & 3.62 & Intermediate \\
\hline $\begin{array}{l}\text { I feel students need to } \\
\text { be trained before } \\
\text { undergoing online } \\
\text { learning activities }\end{array}$ & $\begin{array}{l}2 \\
(3.1 \%)\end{array}$ & $\begin{array}{l}3 \\
(4.6 \%)\end{array}$ & $\begin{array}{l}14 \\
(21.5 \%)\end{array}$ & $\begin{array}{l}21 \\
(32.3 \%)\end{array}$ & $\begin{array}{l}25 \\
(38.5 \%)\end{array}$ & 3.98 & High \\
\hline $\begin{array}{l}\text { I feel that online } \\
\text { learning and enhances } \\
\text { my soft skills }\end{array}$ & $\begin{array}{l}4 \\
(6.2 \%)\end{array}$ & $\begin{array}{l}6 \\
(9.2 \%)\end{array}$ & $\begin{array}{l}20 \\
(30.8 \%)\end{array}$ & $\begin{array}{l}19 \\
(29.2 \%)\end{array}$ & $\begin{array}{l}16 \\
(24.6 \%)\end{array}$ & 3.57 & Intermediate \\
\hline $\begin{array}{l}\text { I feel online learning is } \\
\text { comfortable }\end{array}$ & $\begin{array}{l}5 \\
(7.7 \%)\end{array}$ & $\begin{array}{l}10 \\
(15.4 \%)\end{array}$ & $\begin{array}{l}22 \\
(33.8)\end{array}$ & $\begin{array}{l}20 \\
(30.8 \%)\end{array}$ & $\begin{array}{l}8 \\
(12.3 \%)\end{array}$ & 3.25 & Intermediate \\
\hline $\begin{array}{l}\text { Online learning would } \\
\text { improve my learning } \\
\text { process. }\end{array}$ & $\begin{array}{l}4 \\
(6.2 \%)\end{array}$ & $\begin{array}{l}3 \\
(4.6 \%)\end{array}$ & $\begin{array}{l}22 \\
(33.8)\end{array}$ & $\begin{array}{l}23 \\
(35.4 \%)\end{array}$ & $\begin{array}{l}13 \\
(20 \%)\end{array}$ & 3.58 & Intermediate \\
\hline $\begin{array}{l}\text { Online learning } \\
\text { reduces the time I } \\
\text { spend on unproductive } \\
\text { activities. }\end{array}$ & $\begin{array}{l}4 \\
(6.2 \%)\end{array}$ & $\begin{array}{l}12 \\
(18.5 \%)\end{array}$ & $\begin{array}{l}18 \\
(27.7 \%)\end{array}$ & $\begin{array}{l}20 \\
(30.8 \%)\end{array}$ & $\begin{array}{l}11 \\
(16.9 \%)\end{array}$ & 3.34 & Intermediate \\
\hline $\begin{array}{l}\text { Online learning saves } \\
\text { me money I spend on } \\
\text { printed learning } \\
\text { materials and } \\
\text { transportation cost. }\end{array}$ & $\begin{array}{l}5 \\
(7.7 \%)\end{array}$ & $\begin{array}{l}2 \\
(3.1 \%)\end{array}$ & $\begin{array}{l}17 \\
(26.2 \%)\end{array}$ & $\begin{array}{l}22 \\
(33.8)\end{array}$ & $\begin{array}{l}19 \\
(29.2 \%)\end{array}$ & 3.74 & High \\
\hline $\begin{array}{l}\text { Online } \quad \text { learning } \\
\text { improves my } \text { written }\end{array}$ & $\begin{array}{l}3 \\
(4.6 \%)\end{array}$ & $\begin{array}{l}13 \\
(20 \%)\end{array}$ & $\begin{array}{l}21 \\
(32.3 \%)\end{array}$ & $\begin{array}{l}15 \\
(23.1 \%)\end{array}$ & $\begin{array}{l}13 \\
(20 \%)\end{array}$ & 3.34 & Intermediate \\
\hline
\end{tabular}




\begin{tabular}{|c|c|c|c|c|c|c|c|}
\hline $\begin{array}{l}\text { communication and } \\
\text { analytical thinking } \\
\text { skills. }\end{array}$ & & & & & & & \\
\hline $\begin{array}{l}\text { I feel online learning } \\
\text { orients my study plan. }\end{array}$ & $\begin{array}{l}4 \\
(6.2 \%)\end{array}$ & $\begin{array}{l}2 \\
(3.1 \%)\end{array}$ & $\begin{array}{l}30 \\
(46.2 \%)\end{array}$ & $\begin{array}{l}19 \\
(29.2 \%)\end{array}$ & $\begin{array}{l}10 \\
(15.4 \%)\end{array}$ & 3.45 & Intermediate \\
\hline $\begin{array}{l}\text { I am able to organize } \\
\text { my time well so that } \\
\text { work and tasks do not } \\
\text { build up }\end{array}$ & $\begin{array}{l}4 \\
(6.2 \%)\end{array}$ & $\begin{array}{l}11 \\
(16.9 \%)\end{array}$ & $\begin{array}{l}23 \\
(35.4 \%)\end{array}$ & $\begin{array}{l}15 \\
(23.1 \%)\end{array}$ & $\begin{array}{l}12 \\
(18.5 \%)\end{array}$ & 3.31 & Intermediate \\
\hline $\begin{array}{l}\text { I try to interact with } \\
\text { other students and } \\
\text { instructors during the } \\
\text { courses }\end{array}$ & $\begin{array}{l}5 \\
(7.7 \%)\end{array}$ & $\begin{array}{l}3 \\
(4.6 \%)\end{array}$ & $\begin{array}{l}21 \\
(32.3 \%)\end{array}$ & $\begin{array}{l}24 \\
(36.9 \%)\end{array}$ & $\begin{array}{l}12 \\
(18.5 \%)\end{array}$ & 3.54 & Intermediate \\
\hline $\begin{array}{l}\text { I was satisfied with the } \\
\text { quality of this training } \\
\text { during COVID-19 } \\
\text { pandemic }\end{array}$ & $\begin{array}{l}6 \\
(9.2 \%)\end{array}$ & $\begin{array}{l}8 \\
(12.3 \%)\end{array}$ & $\begin{array}{l}27 \\
(41.5 \%)\end{array}$ & $\begin{array}{l}14 \\
(21.5 \%)\end{array}$ & $\begin{array}{l}10 \\
(15.4 \%)\end{array}$ & 3.22 & Intermediate \\
\hline Overall & & & & & & 3.31 & Intermediate \\
\hline
\end{tabular}

Scale: 5 = strongly agree, 4 = agree, 3 = uncertain, 2 = disagree, and $1=$ strongly disagree.

\section{Technology Characteristics Domain}

The second domain discussed in this section is Technological characteristics domain, which consists of 9 items.(see Table 5). The items that received the highest mean scores were "I have access to a stable internet connection at home" $(M=4.12)$, "Instructions about student participation are clearly presented" (M=3.89), and "I feel internet connection strength determines our effective learning opportunity" (M=3.71). The items that received the intermediate mean score were "I am updated with the latest technology" (M=3.61), "I am satisfied with the content of topic covered during the classes" $(M=3.43)$, "I am able to complete my work even when there was distraction" ( $M=3.41)$, "Online class is effective in bridging the gap of missed academic period" (M=3.34), with the lowest mean score was the item "I feel the course materials are accessible after the completion of each class $(M=3.21)$. Overall, the study reported the students' satisfaction toward technology characteristics can be ranked as intermediate level of mean score $(M=3.66)$. Although it ranked in intermediate level of mean score, the value is very near to high score, which can be concluded that the students have high satisfaction in terms of technology characteristics towards online learning. By having these attitude, it may help the students to always be ready to engage in online learning. This finding in line with the study by Olayemi et al (2021) which stated that the students' skills and competencies in the use and handling the technology play a vital factor in the success of online learning. 
Table 5: Distribution of Responses of the Students in Domain 2 Technology Characteristics $(n=65)$

\begin{tabular}{|c|c|c|c|c|c|c|c|}
\hline Statements & SD & D & $\mathbf{N}$ & A & SA & $\begin{array}{l}\text { Mean } \\
\text { (M) }\end{array}$ & interpretation \\
\hline $\begin{array}{l}\text { I have access to a } \\
\text { stable internet } \\
\text { connection at } \\
\text { home. }\end{array}$ & $2(3.1 \%)$ & $1(1.5 \%)$ & $\begin{array}{l}10 \\
(15.4 \%)\end{array}$ & $\begin{array}{l}26 \\
(40 \%)\end{array}$ & $\begin{array}{l}26 \\
(40 \%)\end{array}$ & 4.12 & High \\
\hline $\begin{array}{l}\text { I am updated with } \\
\text { the latest } \\
\text { technology }\end{array}$ & $4(6.2 \%)$ & $5(7.7 \%)$ & $\begin{array}{l}19 \\
(29.2 \%)\end{array}$ & $\begin{array}{l}21 \\
(32.3 \%)\end{array}$ & $\begin{array}{l}16 \\
(24.6 \%)\end{array}$ & 3.61 & Intermediate \\
\hline $\begin{array}{l}\text { Instructions about } \\
\text { student } \\
\text { participation are } \\
\text { clearly presented }\end{array}$ & 2 (3.1\%) & $1(1.5 \%)$ & $\begin{array}{l}19 \\
(29.2 \%)\end{array}$ & $\begin{array}{l}23 \\
(35.4 \%)\end{array}$ & $\begin{array}{l}20 \\
(30.8 \%)\end{array}$ & 3.89 & High \\
\hline $\begin{array}{l}\text { I repeated the } \\
\text { online instructional } \\
\text { materials based on } \\
\text { my needs. }\end{array}$ & $\begin{array}{l}7 \\
(10.8 \%)\end{array}$ & $\begin{array}{l}8 \\
(12.3 \%)\end{array}$ & $\begin{array}{l}22 \\
(33.8)\end{array}$ & $\begin{array}{l}18 \\
(27.7 \%)\end{array}$ & $\begin{array}{l}10 \\
(15.4 \%)\end{array}$ & 3.25 & Intermediate \\
\hline $\begin{array}{l}\text { I feel internet } \\
\text { connection strength } \\
\text { determines our } \\
\text { effective learning } \\
\text { opportunity. }\end{array}$ & $4(6.2 \%)$ & 0 & $\begin{array}{l}19 \\
(29.2 \%)\end{array}$ & $\begin{array}{l}30 \\
(46.2 \%)\end{array}$ & $\begin{array}{l}12 \\
(18.5 \%)\end{array}$ & 3.71 & High \\
\hline $\begin{array}{l}\text { I feel the course } \\
\text { materials are } \\
\text { accessible after the } \\
\text { completion of each } \\
\text { class }\end{array}$ & $3(4.6 \%)$ & 0 & $\begin{array}{l}8 \\
(12.3 \%)\end{array}$ & $\begin{array}{l}23 \\
(35.4 \%)\end{array}$ & $\begin{array}{l}31 \\
(47.7 \%)\end{array}$ & 4.21 & High \\
\hline $\begin{array}{l}\text { I am able to } \\
\text { complete my work } \\
\text { even when there } \\
\text { were distraction }\end{array}$ & $5(7.7 \%)$ & $4(6.2 \%)$ & $\begin{array}{l}26 \\
(40 \%)\end{array}$ & $\begin{array}{l}19 \\
(29.2 \%)\end{array}$ & $\begin{array}{l}11 \\
(16.9 \%)\end{array}$ & 3.41 & Intermediate \\
\hline $\begin{array}{l}\text { I am satisfied with } \\
\text { the content of topic } \\
\text { covered during the } \\
\text { classes }\end{array}$ & $4(6.2 \%)$ & $\begin{array}{l}8 \\
(12.3 \%)\end{array}$ & $\begin{array}{l}21 \\
(32.3 \%)\end{array}$ & $\begin{array}{l}20 \\
(30.8 \%)\end{array}$ & $\begin{array}{l}12 \\
(18.5 \%)\end{array}$ & 3.43 & Intermediate \\
\hline $\begin{array}{l}\text { Online class is } \\
\text { effective in bridging } \\
\text { the gap of missed } \\
\text { academic period. }\end{array}$ & $6(9.2 \%)$ & $6(9.2 \%)$ & $\begin{array}{l}25 \\
(38.5 \%)\end{array}$ & $\begin{array}{l}16 \\
(24.6 \%)\end{array}$ & $\begin{array}{l}12 \\
(18.5 \%)\end{array}$ & 3.34 & Intermediate \\
\hline Overall & & & & & & 3.66 & Intermediate \\
\hline
\end{tabular}

Scale: 5 = strongly agree, 4 = agree, $3=$ uncertain, 2 = disagree, and $1=$ strongly disagree.

Instructor Characteristics Domain

The third domain is Instructor Characteristics which consisted of 13 items as reported in Table 6. Out of 13 items, the items that obtained the highest mean scores were "I feel that my lecturers provide opportunities to ask questions" ( $M=3.97)$, "I feel that my lecturers have 
good content knowledge" ( $M=3.83)$, "I am satisfied with the quality of graphic aids such as sound and picture (ppt) being displayed by lecturers" ( $M=3.78)$, "I feel that my lecturers treated me with respect" $(M=3.77)$. The item that earned the lowest score was "I feel the response time from lecturers is quicker in online courses" $(M=3.42)$.

Table 6: Distribution of Responses of the Students in Domain 3 Instructor Characteristics $(n=65)$

\begin{tabular}{|c|c|c|c|c|c|c|c|}
\hline Statements & SD & D & $\mathbf{N}$ & A & SA & $\begin{array}{l}\text { Mean } \\
\text { (M) }\end{array}$ & Interpretation \\
\hline $\begin{array}{l}\text { I feel that my } \\
\text { lecturers have good } \\
\text { content } \\
\text { knowledge. }\end{array}$ & $\begin{array}{l}3 \\
(4.6 \%)\end{array}$ & $\begin{array}{l}3 \\
(4.6 \%)\end{array}$ & $\begin{array}{l}17 \\
(26.2 \%)\end{array}$ & $\begin{array}{l}21 \\
(32.3 \%)\end{array}$ & $\begin{array}{l}21 \\
(32.3 \%)\end{array}$ & 3.83 & High \\
\hline $\begin{array}{l}\text { I feel that my } \\
\text { lecturers provide } \\
\text { opportunities to } \\
\text { ask questions }\end{array}$ & $\begin{array}{l}3 \\
(4.6 \%)\end{array}$ & $\begin{array}{l}1 \\
(1.5 \%)\end{array}$ & $\begin{array}{l}12 \\
(18.5 \%)\end{array}$ & $\begin{array}{l}28 \\
(43.1 \%)\end{array}$ & $\begin{array}{l}21 \\
(32.3 \%)\end{array}$ & 3.97 & High \\
\hline $\begin{array}{l}\text { I feel that my } \\
\text { lecturers treated } \\
\text { me with respect }\end{array}$ & $\begin{array}{l}4 \\
(6.2 \%)\end{array}$ & $\begin{array}{l}2 \\
(3.1 \%)\end{array}$ & $\begin{array}{l}17 \\
(26.2 \%)\end{array}$ & $\begin{array}{l}24 \\
(36.9 \%)\end{array}$ & $\begin{array}{l}18 \\
(27.7 \%)\end{array}$ & 3.77 & High \\
\hline $\begin{array}{ll}\text { I feel that my } \\
\text { lecturers } & \\
\text { understood } & \mathrm{my} \\
\text { learning needs } & \end{array}$ & $\begin{array}{l}6 \\
(9.2 \%)\end{array}$ & $\begin{array}{l}3 \\
(4.6 \%)\end{array}$ & $\begin{array}{l}18 \\
(27.7 \%)\end{array}$ & $\begin{array}{l}20 \\
(30.8 \%)\end{array}$ & $\begin{array}{l}18 \\
(27.7 \%)\end{array}$ & 3.63 & Intermediate \\
\hline $\begin{array}{l}\text { I feel that my } \\
\text { lecturers made the } \\
\text { subject } \\
\text { interesting } \\
\text { possible }\end{array}$ & $\begin{array}{l}6 \\
(9.2 \%)\end{array}$ & $\begin{array}{l}2 \\
(3.1 \%)\end{array}$ & $\begin{array}{l}21 \\
(32.3 \%)\end{array}$ & $\begin{array}{l}20 \\
(30.8 \%)\end{array}$ & $\begin{array}{l}16 \\
(24.6 \%)\end{array}$ & 3.59 & Intermediate \\
\hline $\begin{array}{l}\text { I feel the response } \\
\text { time from lecturers } \\
\text { is quicker in online } \\
\text { courses }\end{array}$ & $\begin{array}{l}6 \\
(9.2 \%)\end{array}$ & $\begin{array}{l}8 \\
(12.3 \%)\end{array}$ & $\begin{array}{l}18 \\
(27.7 \%)\end{array}$ & $\begin{array}{l}19 \\
(29.2 \%)\end{array}$ & $\begin{array}{l}14 \\
(21.5 \%)\end{array}$ & 3.42 & Intermediate \\
\hline $\begin{array}{lr}\text { I am satisfied } & \text { with } \\
\text { lecturers } & \text { in } \\
\text { providing } & \text { clear } \\
\text { instructions } & \end{array}$ & $\begin{array}{l}4 \\
(6.2 \%)\end{array}$ & $\begin{array}{l}2 \\
(3.1 \%)\end{array}$ & $\begin{array}{l}19 \\
(29.2 \%)\end{array}$ & $\begin{array}{l}27 \\
(41.5 \%)\end{array}$ & $\begin{array}{l}13 \\
(20 \%)\end{array}$ & 3.66 & Intermediate \\
\hline $\begin{array}{l}\text { I am satisfied with } \\
\text { the lecturers' } \\
\text { accessibility during } \\
\text { the class }\end{array}$ & $\begin{array}{l}5 \\
(7.7 \%)\end{array}$ & $\begin{array}{l}1 \\
(1.5 \%)\end{array}$ & $\begin{array}{l}20 \\
(30.8 \%)\end{array}$ & $\begin{array}{l}24 \\
(36.9 \%)\end{array}$ & $\begin{array}{l}15 \\
(23.1 \%)\end{array}$ & 3.66 & Intermediate \\
\hline $\begin{array}{l}\text { I am satisfied with } \\
\text { the lecturers' pace } \\
\text { of punctuality }\end{array}$ & $\begin{array}{l}4 \\
(6.2 \%)\end{array}$ & $\begin{array}{l}2 \\
(3.1 \%)\end{array}$ & $\begin{array}{l}15 \\
(23.1 \%)\end{array}$ & $\begin{array}{l}31 \\
(47.7 \%)\end{array}$ & $\begin{array}{l}13 \\
(20 \%)\end{array}$ & 3.72 & High \\
\hline
\end{tabular}




\begin{tabular}{|c|c|c|c|c|c|c|c|}
\hline $\begin{array}{l}\text { I am satisfied with } \\
\text { the lecturers in } \\
\text { reviewing the topic } \\
\text { covered in the } \\
\text { previous sessions }\end{array}$ & $\begin{array}{l}4 \\
(6.2 \%)\end{array}$ & $\begin{array}{l}4 \\
(6.2 \%)\end{array}$ & $\begin{array}{l}17 \\
(26.2 \%)\end{array}$ & $\begin{array}{l}26 \\
(40 \%)\end{array}$ & $\begin{array}{l}14 \\
(21.5 \%)\end{array}$ & 3.65 & \\
\hline $\begin{array}{l}\text { I am satisfied with } \\
\text { the lecturers' } \\
\text { supportiveness } \\
\text { towards my } \\
\text { questions }\end{array}$ & $\begin{array}{l}4 \\
(6.2 \%)\end{array}$ & $\begin{array}{l}3 \\
(4.6 \%)\end{array}$ & $\begin{array}{l}15 \\
(23.1 \%)\end{array}$ & $\begin{array}{l}29 \\
(44.6 \%)\end{array}$ & $\begin{array}{l}14 \\
(21.5 \%)\end{array}$ & 3.71 & High \\
\hline $\begin{array}{l}\text { I am satisfied with } \\
\text { the lecturers' } \\
\text { responsiveness } \\
\text { towards my } \\
\text { questions }\end{array}$ & $\begin{array}{l}4 \\
(6.2 \%)\end{array}$ & $\begin{array}{l}2 \\
(3.1 \%)\end{array}$ & $\begin{array}{l}16 \\
(24.6 \%)\end{array}$ & $\begin{array}{l}28 \\
(43.1 \%)\end{array}$ & $\begin{array}{l}15 \\
(23.1 \%)\end{array}$ & 3.74 & High \\
\hline $\begin{array}{l}\text { I am satisfied with } \\
\text { the quality of } \\
\text { graphic aids such as } \\
\text { sound and picture } \\
\text { (ppt) being } \\
\text { displayed by } \\
\text { lecturers }\end{array}$ & $\begin{array}{l}4 \\
(6.2 \%)\end{array}$ & $\begin{array}{l}3 \\
(4.6 \%)\end{array}$ & $\begin{array}{l}14 \\
(21.5 \%)\end{array}$ & $\begin{array}{l}26 \\
(40 \%)\end{array}$ & $\begin{array}{l}18 \\
(27.7 \%)\end{array}$ & 3.78 & High \\
\hline Overall & & & & & & 3.70 & High \\
\hline
\end{tabular}

Scale: 5 = strongly agree, 4 = agree, 3 = uncertain, 2 = disagree, and 1 = strongly disagree.

Overall Students' Satisfaction towards Online Learning

Figure 1 below depicts that $58.5 \%$ of the students were satisfied or fully satisfied towards the online classes being conducted. Only $13.8 \%$ of them were dissatisfied or fully dissatisfied with the online classes. The remaining $27.7 \%$ gave neutral scores. This finding indicates that satisfaction rate was lower compared to other studies, where satisfaction rates as high as 93.4\% have been reported by Seada (2017) and Singh \& Min (2017). The students may be more familiar with the traditional learning environment and students could feel that they are generally more isolated in the virtual learning environment. 


\section{Figure 1: Overall Students' Satisfaction towards Online Learning $(n=65)$}

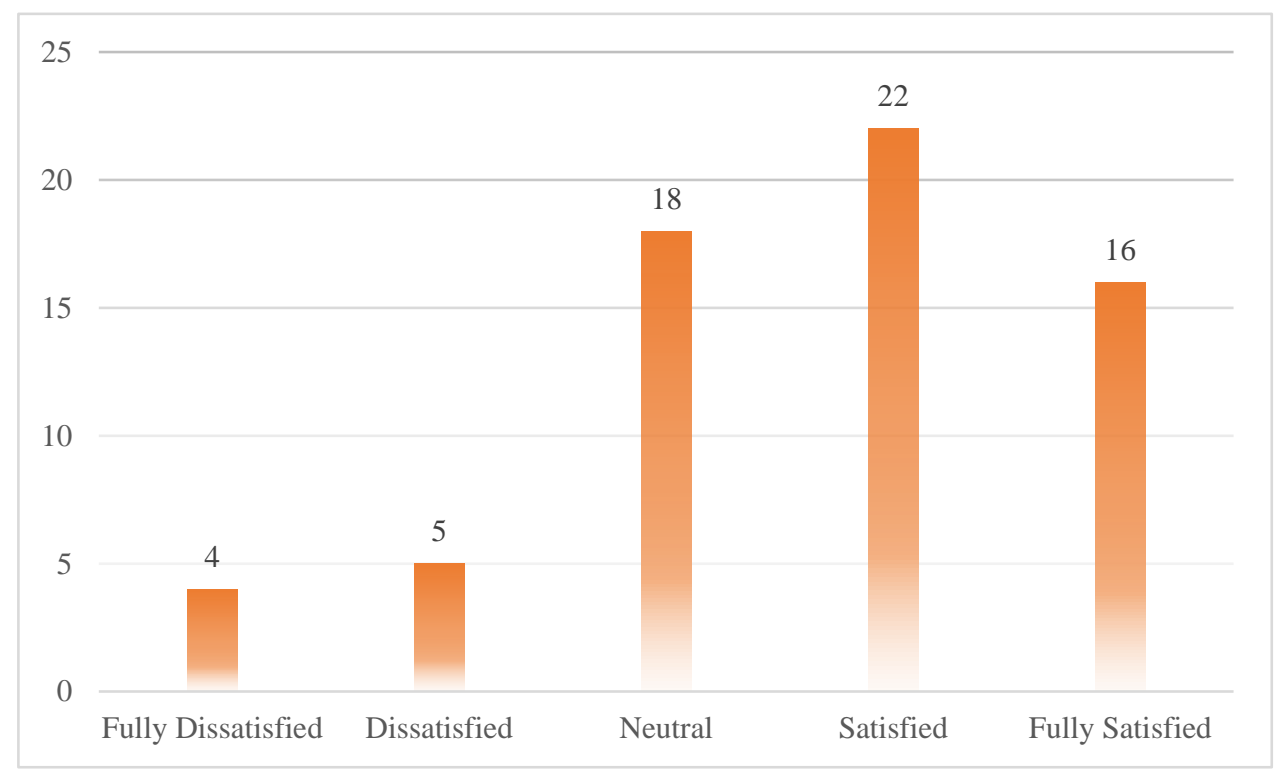

\section{Conclusion}

The present study investigates the satisfaction of undergraduate students towards online learning during the ongoing COVID-19 pandemic. The study reveals the preferences of students for online learning as it provides them much freedom to connect with their teachers, students and engage with their course materials at the comfort and flexibility of their own space and time. The findings of this study are consistent with previous studies, in which that well-designated components of online learning can caused demotivation among students. In turn, the student' satisfaction with online learning may affect academic achievement.

The findings of this study imply that the online learning and teaching in Malaysia required improvement to be done, especially in terms of quality of the interaction and instruction delivered during the course. Even though the respondents are satisfied with the instructor, course management, and also the technology dimension, some improvements should be implemented to enhance the delivery of online teaching and learning in Malaysia. Overall, the students are coping with the work from the home period, but there was dissatisfaction with certain elements. The universities should act accordingly before losing their clients (students) due to this pandemic.

The result from this study important because they come from the students that did not chose to do online learning, but because of the pandemic COVID-19, they had go through online learning for almost all of their courses. The results from this study may provide useful information for online course designers and instructors on how to improve the existing online courses to be more effective. It should also include design characteristics that enhance students' positive satisfaction which then will lead to greater students' academic achievement.

\section{References}

Alawamleh, M. (2020). COVID-19 and higher education economics. Journal of Economics and Economic Education Research, Vol. 21 No. 2, pp. 1-2.

Algahtani, A. F. (2011) Evaluating the effectiveness of the e-learning experience in some universities in Saudi Arabia from male students' perceptions. Durham theses, Durham University, UK. 
Chung, E., \& Mathew, V. N. (2020). Satisfied with online learning amidst COVID-19, but do you intend to continue using it. International Journal of Academic Research in Progressive Education and Development, 9(4), 67-77.

Cidral, W. A., Oliveira, T., Di Felice, M., Aparicio, M. (2018). E-learning success determinants: Brazilian empirical study. Computers \& Education.;122:273-90.

Cole, M. T., Shelley, D. J., \& Swartz, L. B. (2014). Online instruction, e-learning, and student satisfaction: A three year study. The International Review of Research in Open and Distributed Learning, 15(6).

Dawadi, S., Giri, R., Simkhada, P. (2020) Impact of COVID-19 on the Education Sector in Nepal: Challenges and Coping Strategies.

Dhawan, S. (2020) Online learning: a panacea in the time of COVID-19 crisis. Journal of Educational Technology Systems 0(0): 1-18.

Dziuban, C., Moskal, P., Thompson, J., Kramer, L., DeCantis, G., \& Hermsdorfer, A. (2015). Student satisfaction with online learning: Is it a psychological contract? Journal of Asynchronous Learning Network. https://doi.org/10.24059/olj.v19i2.496

Gray, J. A., \& DiLoreto, M. (2016). The Effects of Student Engagement, Student Satisfaction, and Perceived Learning in Online Learning Environments This. NCPEA International Journal of Educational Leadership Preparation.

Hair, J. F., Black, W. C., Babin, B. J., Anderson, R. E., \& Tatham, R. L. (2006). Multivariate Data Snalysis, (Vol. 6); Pearson Prentice Hall: Upper Saddle River, NJ, USA.

Harsasi, M., \& Sutawijaya, A. (2018). Determinants of student satisfaction in online tutorial: A study of a distance education institution. Turkish Online Journal of Distance Education. https://doi.org/10.17718/tojde.382732

Mahajan, M. V. (2018). A study of students' perception about e-learning. Indian J. Clin. Anat. Physiol, 5.

Mishra, L., Gupta, T., \& Shree, A. (2020). Online teaching-learning in higher education during lockdown period of COVID-19 pandemic. International Journal of Educational Research Open. https://doi.org/10.1016/j.ijedro.2020.100012

Mustapah, J., \& Rosli, R. (2021). Tahap Kepuasan Pembelajaran Matematik Atas Talian Semasa Pandemik COVID-19. Malaysian Journal of Social Sciences and Humanities (MJSSH), 6(4), 1-20.

Nortvig, A. M., Petersen, A. K., \& Balle, S. H. (2018). A literature review of the factors influencing elearning and blended learning in relation to learning outcome, student satisfaction and engagement. Electronic Journal of E-Learning.

Olayemi, O. M., Adamu, H., \& Olayemi, K. J. (2021). Perception and Readiness of Students' Towards Online Learning in Nigeria During Covid-19 Pandemic. Perception, 3, 4-2021.

Parahoo, S. K., Santally, M. I., Rajabalee, Y., \& Harvey, H. L. (2016). Designing a predictive model of student satisfaction in online learning. Journal of Marketing for Higher Education, 26(1), 1-19.

Pei, L., Wu, H. (2019). Does online learning work better than offline learning in undergraduate medical education? A systematic review and meta-analysis. Medical Education Online. 24(1):1666538.

Rios, T., Elliott, M., \& Mandernach, B. J. (2018). Efficient instructional strategies for maximizing online student satisfaction. Journal of Educators Online. https://doi.org/10.9743/jeo.2018.15.3.7

Sá, M. J., Serpa, S. (2020). The COVID-19 Pandemic as an Opportunity to Foster the Sustainable Development of Teaching in Higher Education. Sustainability 2020, 12, 8525. 
Seada, Al., Mostafa, M. F. (2017). Students' Satisfaction and Barriers of E-Learning Course among Nursing Students, Mansoura University. IDOSI Publications. 3 (3): 170-178, 2017.

Sekaran, U., Bougie, R. (2016). Research Methods for Business: A Skill Building Approach. New York, NY, USA: John Wiley \& Sons.

Shen, C., \& Chuang, H. (2010). Exploring users' attitudes and intentions toward the interactive whiteboard technology environment. International Review on Computers and Software, 5(2), 200-208.

Singh, V., Thurman, A. (2019) How many ways can we define online learning? A systematic literature review of definitions of online learning (1988-2018). American Journal of Distance Education 33(4): 289-306.

Singh, A., Min, A. K. (2017). Digital lectures for learning gross anatomy: A study of their efficacy. Korean Journal of Medical Education. 29(1):27.

The Regional Risk Communication and Community Engagement (RCCE) Working Group. (2020) COVID19: How to include marginalized and vulnerable people in risk communication and community engagement. Available at: https://reliefweb.int/sites/reliefweb.int/files/resources/COVID19_CommunityEngage ment_130320.pdf (accessed 10 July, 2021).

UNESCO. (2020). 1.37 billion students now home as COVID-19 school closures expand, ministers scale up multimedia approaches to ensure learning continuity. Unesco.

UNESCO. (2020). Distance learning strategies in response to COVID-19 school closures. In UNESCO COVID-19 Education Response Education Sector issue notes.

World Health Organization. (2020). WHO Director-General's Opening Remarks at the Media Briefing on COVID-19 -11 March 2020. Available online at: https://www.who.int/dg/speeches/detail/who-director-general-s-opening-remarksat-the-media-briefing-on-covid-19---11-march-202 (accessed July 3, 2021). 